\title{
РЕАЛІЗАЦІЯ ПРОЕКТІВ ДЕРЖАВНО-ПРИВАТНОГО ПАРТНЕРСТВА В АГРАРНОМУ СЕКТОРІ
}

Круглов В. B., д-р. наук з держ. упр., доцент, Харківський національний університет будівництва та архітектури, м. Харків, Україна.

Терещенко Д. А., д-р. наук 3 держ. упр., доцент, Харківський національний університет будівництва та архітектури, м. Харків, Україна.

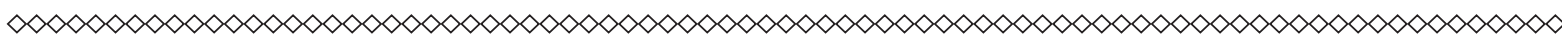

У дослідженні проаналізовано сучасний стан розвитку державно-приватного партнерства, місие аграрного сектору економіки України у формуванні валового внутрішнього продукту та досліджено ключові напрями співробітництва держави та приватного власника на основі реалізації проектів у аграрному секторі. Метою статті - є аналіз реалізації проєктів державно-приватного партнерства в аграрному секторі економіки та розробка підходів щзодо активізації стратегічних напрямів розвитку партнерства державного та приватного власника в аграрному секторі. В основі сучасних підходів до розвитку аграрного сектору мають знаходитися пріоритети, спрямовані на пошук додаткових ресурсів, які можливо залучити у процесі реалізації проєктів державно-приватного партнерства. У дослідженні визначено основні напрями розвитку державно-приватного партнерства в аграрному секторі, щзо передбачає обмін знаннями, розроблення комплексних стратегій, кониесійні угоди, створення особливих економічних зон, технопарків i технополісів, формування інтегрованих структур, кластерів та інвестиційних фондів, розвиток ланщюгів створення вартості. Buокремлено, на основі існуючого практичного досвіду, основні форми реалізації проєктів державно-приватного партнерства. Запропоновано напрями реалізації проєктів державно-приватного парт- 
нерства у окремих галузях аграрного сектору на основі створення та модернізації об 'єктів інфраструктури та технологій просування продукиії на ринку. Розроблено модель реалізації стратегічного планування розвитку сфер діяльності, пов'язаних з аграрним сектором, на основі можливого використання проєктів державноприватного партнерства. В якості основних інструментів у розвитку проєктів державно-приватного партнерства в аграрному секторі запропоновано формування Стратегії розвитку сільського господарства, реалізацію сільськогосподарських кластерних проєктів та ланцюгів доданої вартості, податкове стимулювання інноваційної діяльності в аграрному секторі, поліпшення інвестиційного клімату, створення технологічних парків та бізнес-інкубаторів, удосконалення законодавчої бази, інноваційний розвиток та ін.

Ключові слова: державно-приватне партнерство, аграрний сектор, держава, проекти, інновачійний розвиток, стратегії.

Постановка проблеми у загальному вигляді. Потреби пошуку дієвих підходів до впровадження сучасних моделей господарювання, додаткових інструментів залучення інвестиційних ресурсів, які дадуть можливість реалізувати наявний галузевий потенціал аграрного сектору економіки, враховуючи ключову роль останнього у формуванні продовольчої безпеки, збільшенні експортного потенціалу держави, забезпеченні сільськогосподарською продукцією внутрішнього ринку, вимагає від держави активної діяльності у вирішенні зазначених питань. Окремі розрахунки демонструють, що в період 2020-2030 рр. в аграрному секторі є необхідність залучення близько 46 млрд дол. США інвестицій [1]. Визнаючи необхідність значних фінансових потреб для подальшого розвитку аграрної галузі, доцільність використання управлінського досвіду та необхідних компетенцій у сучасних інфраструктурних проєктах, інноваційного інструментарію господарської діяльності, посилення соціальних складників у підприємницькій діяльності, суттєвим стає зміщення акцентів на використання партнерських відносин між представниками різних форм власності для досягнення спільних 
цілей. Результати співпраці держави та приватного сектору у реалізації інфраструктурних проектів державно-приватного партнерства (ДПП) у транспортній, енергетичній, інформаційній, освітній та інших сферах доводять перспективність зазначеного способу організації господарської діяльності, яка задовольняє суспільні потреби. Світовий досвід демонструє, що використання в аграрному секторі моделей державно-приватного партнерства, сприятиме проведенню модернізації, залучить в галузь необхідні ресурси та розширить можливості, що дозволить розширити виробництво та посилити конкурентні переваги галузі.

Аналіз останніх досліджень та публікацій. Дослідженню питань формування напрямів розвитку державно-приватного партнерства в аграрному секторі економіки приділяється підвищена увага дослідників. Зокрема, О. Радченко [2] визначив механізми й інструменти ДПП в аграрному секторі національної економіки, які $є$ найбільш оптимальними та дієвими. І. Косач та Г. Старченко [3] обгрунтували необхідність використання механізму державноприватного партнерства в агропромисловому комплексі. М. Козін, Г. Пирченкова та С. Радченко [4], досліджуючи організаційно-економічні механізми розвитку аграрного сектору, в якості формування зазначених механізмів вбачають державно-приватне партнерство. Х. Григор'єва [5] досліджуючи реалізацію ДПП у сільському господарстві, надає пропозиції щодо механізмів фінансової підтримки аграрного сектору економіки України з боку держави. М. Латинін і О. Заскалкіна [6] досліджують підходи щодо поліпшення інституціонального середовища в аграрному секторі за рахунок покращення інвестиційного клімату та створення аграрних кластерів та агротехнопарків. Т. Ратушна [7] пропонує використання ДПП в сільському господарстві як об’єднання ресурсів, що дозволить ефективно використовувати бюджетні кошти. Зважаючи на актуальність питання, зазначена проблематика потребує розгляду окремих підходів до визначення ключових напрямів розвитку державно-приватного партнерства в аграрному секторі.

Формулювання цілей статті (постановка завдання). Метою статті $-\epsilon$ аналіз реалізації проєктів державно-приватного партнер- 
ства в аграрному секторі економіки та розробка підходів щодо активізації стратегічних напрямів розвитку партнерства державного та приватного власника в аграрному секторі.

Виклад основного матеріалу дослідження. Для досягнення встановлених цільових показників у різних сферах діяльності необхідно визначити доцільність застосування певних підходів, правил, дій та можливих напрямів діяльності, що передбачає використання наявних ресурсних можливостей, механізмів, методів, засобів і ефективного інструментарію у системі державного управління. Зазначене бачення формулюється у вигляді відповідної державної політики, що реалізує ключові державні інтереси. Формування державної політики передбачає встановлення цільових орієнтирів та пріоритетів; визначення умов реалізації політики; розроблення послідовних завдань для реалізації вибраної політики; вибір відповідних інструментів і дій; діагностика проблемних ситуацій [8]. Визначені галузевими стратегічними законодавчими актами завдання щодо соціально-економічного розвитку, підвищення рівня життя, забезпечення продовольством, реагування на динамічні зміни зовнішнього середовища в сьогоднішніх умовах неможливо вирішити окремо за рахунок державного або приватного власника, що передбачає необхідність використання в державній секторальній політиці моделей управління заснованих на ефективності та конкуренції, проектного фінансування, які виникають за рахунок об'єднання можливостей державного та приватного сектору в аграрній сфері економіки.

Аграрний сектор економіки відіграє ключову роль у нарощуванні продовольчого ресурсу, посиленні позицій на зовнішніх товарних ринках, забезпеченні національної безпеки. Глобальна додана вартість, створювана сільським господарством, лісовим господарством та рибальством, зросла на $68 \% 32000$ р. до 2018 р., досягнувши у 2018 р. в грошовому виразі 3,4 трлн дол. США, що демонструє збільшення на 1,4 трлн. дол. США порівняно з 2000 р. Збільшився майже на 50 \% з 2000 р. до 2018 р. (до 9,1 млрд т.) загальний обсяг виробництва первинних культур. виробництво м'яса в 2018 р. у світі досягло 342 млн. т, що на 47 \% більше на 109 млн т) порівняно 3 
2000 р. Площа зрошуваних сільськогосподарських земельних ділянок досягла в 2018 р. 339 млн. га, що на 17 \% більше порівняно 3 2000 р. Вартість світового експорту продовольчих товарів збільшилася в період 2000-2018 pр. із 380 млрд. дол. США до майже 1,4 трлн дол США у 2018 р., зі значним зростанням у всіх продовольчих товарних групах [9]. Зростання попиту на сільськогосподарську продукцію (перероблені харчові продукти, продукти тваринного походження, молочні продукти, зернові, коренеплоди та біопаливо) до 2024 р. буде зумовлено країнами, що розвиваються [10].

Зазначене свідчить про зростання обсягів у аграрній сфері, що зумовлює потреби збільшення кількості працівників галузі. Слід зазначити, що на аграрний сектор України припадає 15\% зайнятості. Експорт агропродовольчих товарів становить близько 40\% загального експорту України [11]. Очікується, що Україна постійно нарощуватиме частку у світовій торгівлі та досягне $12 \%$ світового експорту в 2029 р. За прогнозами, Україна збільшить урожайність на 1,5 \% в рік, за умови збільшення сівозміни в поєднанні з кращими аграрними практиками та відмовою від непродуктивних земель [12]. За рахунок підвищення продуктивності сільського господарства в останнє десятиріччя частка продовольчих товарів у структурі українського експорту збільшилася у двічі до 47 \% за 9 місяців 2020 p. (21\% у 2010 р.). Важливою характеристикою аграрного сектору $\epsilon$ підвищена стійкість експорту сільськогосподарської продукції до кризових ситуацій в економіці, що відображає низьку еластичність попиту на продовольство за доходом (при зниженні доходів попит на нього скорочується помірніше у порівнянні з іншими товарами). Таким чином, у структурі українського експорту висока частка продовольчих товарів пом'якшила ситуацію під час економічної кризи у 2020 р. [13].

Виходячи 3 викладеного, слід зазначити, що аграрна сфера відіграє суттєву роль у розвитку України, але стратегічні кроки передбачають залучення інвестиційних ресурсів, впровадження нових технологій з високою доданою вартістю, перехід на сучасні форми господарювання. Одним із способів, що може посилити позиції аграрного сектору в Україні, забезпечити додатковими ресурсами та 
інноваційними підходами до розвитку галузі може стати розповсюджена у світовій практиці модель взаємодії державного та приватного сектору - державно-приватне партнерство. Поява ДПП в аграрному секторі економіки є посиленням потреб у наданні суспільних благ, таких як наприклад, забезпечення продовольчої безпеки, захист навколишнього середовища, посилення життєздатності сільських районів [14].

Останніми десятиліттями державне управління віднаходить інноваційні підходи до посилення власних можливостей. Для вирішення все більшої кількості суспільних завдань, державних ресурсів виявляється недостатньо, аби якісно виконувати власні функції. Тому з'являються гібридні форми управління, які дозволяють делегувати частину власних функцій держави тому, хто може це реалізувати більш ефективно, а саме - приватному власнику. Ідеями зазначеного підходу стали концепції Нового публічного менеджменту, що базується на мінімізації ролі держави, децентралізації функцій управління, ринковій орієнтації публічних служб, укладанні контрактів, результативності, конкуренції. Новий публічний менеджмент пропагував державно-приватне партнерство як інструмент, що поєднує найкращі вигоди державного та приватного секторів у забезпеченні інфраструктури, тим самим зменшуючи фінансове навантаження на державу та досягаючи ефективності у реалізації проектів У рамках парадигми Нового публічного менеджменту ключовими інституційними можливостями, що підтримують державне використання ДПП, визначаються верховенство права, довіра та потенціал [15].

Державно-приватне партнерство розглядається як «довгостроковий контракт між приватною стороною та державними органами на надання державного майна або послуги, в якому приватна сторона несе значний ризик та відповідальність за управління, а винагорода пов'язана з результатами діяльності» [16]. У ситуації дефіциту державних фінансів, зношення інфраструктури, збільшення дефіциту інфраструктурних об'єктів та вимог для досягнення Цілей сталого розвитку ООН щодо інфраструктурного забезпечення, країни сьогодні стикаються з проблемами у інфраструктурному розвитку 
[17]. Ці проблеми заважають швидкому та стійкому прогресу в економічному зростанні та зменшенні нерівності. У цьому контексті державно-приватні партнерства розглядаються як альтернативне рішення для подолання існуючого дефіциту інфраструктури в країнах, які не можуть фінансувати з бюджету інфраструктуру та позбавлені переваг, пов'язаних з розвитком інфраструктури. Сьогодні модель ДПП використовується для задоволення зростаючих потреб у інфраструктурі у багатьох країнах [18].

Окрім зменшення фіскального навантаження країн, ДПП пропонують і інші переваги: залучають приватні кошти, забезпечують економію коштів та часу, допомагають досягти кращого співвідношення ціни та якості та забезпечують належний розподіл ризиків [19]. Домовленості про ДПП передбачають співпрацю, а також розподіл відповідальності, а основною метою є акумулювання ресурсів для побудови інфраструктури. ДПП можуть використовуватися для фінансування інфраструктури в енергетиці, транспорті, інформаційно-комунікаційних технологіях, водопостачанні та каналізації, санітарії та соціальному секторі [18]. ДПП може бути успішним лише в тому випадку, якщо робоча домовленість між державним та приватним секторами є гармонійною, керівники проєктів ДПП відіграють важливу роль у формуванні добрих відносин між обома сторонами, демонструючи підхід щодо розподілу влади, довіри та готовності до переговорів [20].

У процесі реалізації масштабних інфраструктурних проектів можуть бути різні варіанти участі суб'єктів: представників державного чи комунального сектору та представників приватного сектору в межах угод щодо державно-приватного партнерства (рис. 1).

Сучасний стан розвитку державно-приватного партнерства у світі характеризується значною кількістю проектів та загального обсягу інвестиційних залучень. Динаміку кількості проектів в країнах, що розвиваються, та суми інвестиційних коштів за період 20152020 pp. [22] показано на рис. 2. Запропонована вибірка враховує інформацію про інфраструктурні проекти країн, які мають низький та середній рівень доходів. 


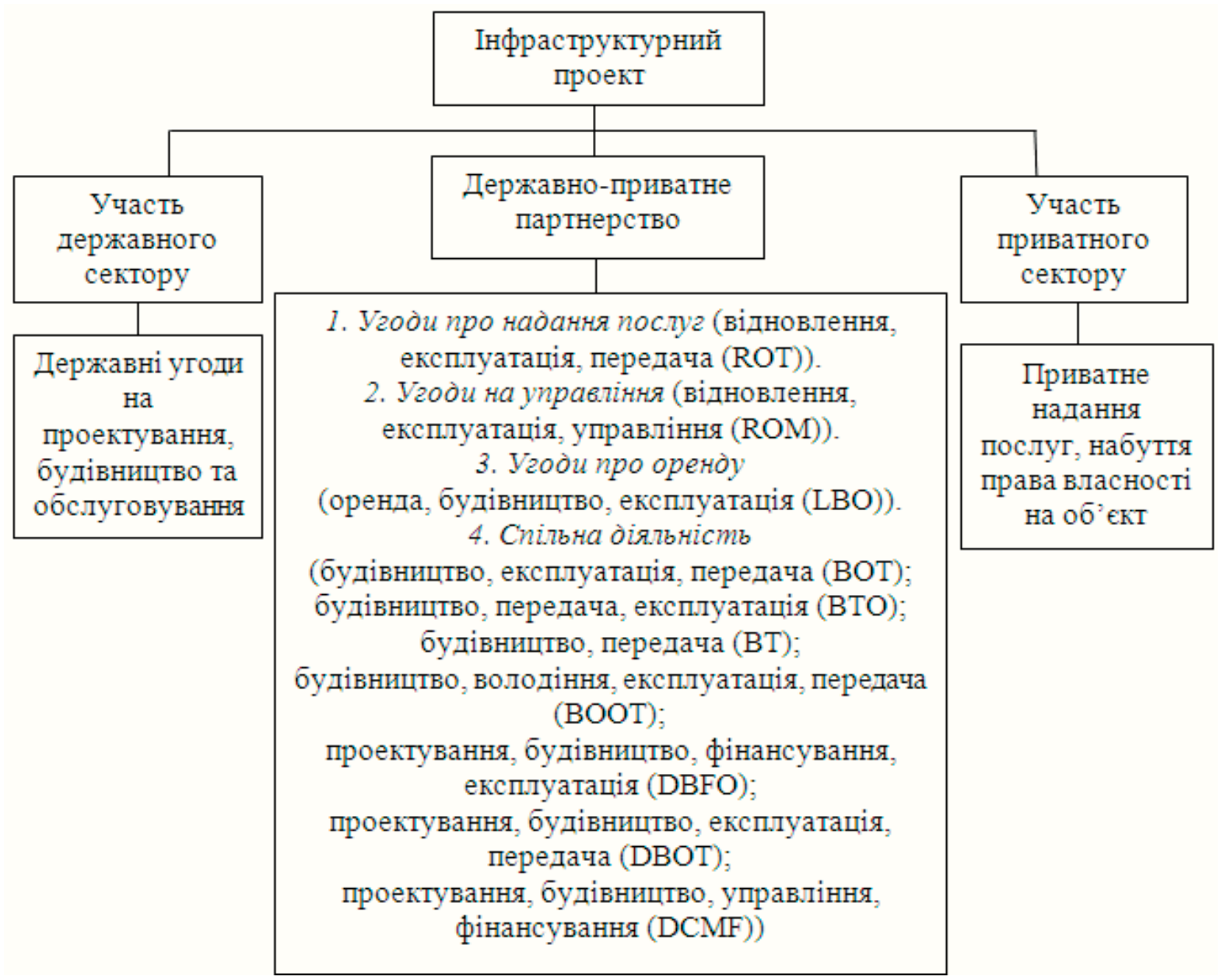

Puc. 1. Реалізація інфраструктурних проектів зі ступенем залучення та інвестиційній відповідальності [21]

За даними звіту «Приватна участь в інфраструктурі» [23], оприлюдненого Світовим банком, у 2020 році, приватні інвестиційні зобов'язання в сфері енергетики; транспорту; інформаційно-комунікаційних технологій; водопостачання та нещодавно включеної інфраструктури щодо поводження 3 твердими побутовими відходами у країнах 3 низьким та середнім рівнем доходу склали 45,7 млрд. дол. США за 252 проектами, що на 52 \% нижче рівня 2019 р. Тим не менше, незважаючи на триваючу пандемію, інвестиції у другій половині року зросли на 15 \% порівняно з першим півріччям 2020 p. Інвестиційні зобов'язання транспортного сектору були найнижчими за останнє десятиліття як за кількістю проектів, так і за рівнем інвестицій. Із 129 проектів з виробництва електроенергії 117 про- 
водились у секторі відновлюваних джерел енергії. Енергетичний сектор залучив 29,8 млрд. дол США у 145 проектів. Сектор переробки твердих побутових відходів отримав 1 млрд. дол США на 19 проектів, а у сектор водопостачання залучено 4 млрд. дол США на 46 проектів.

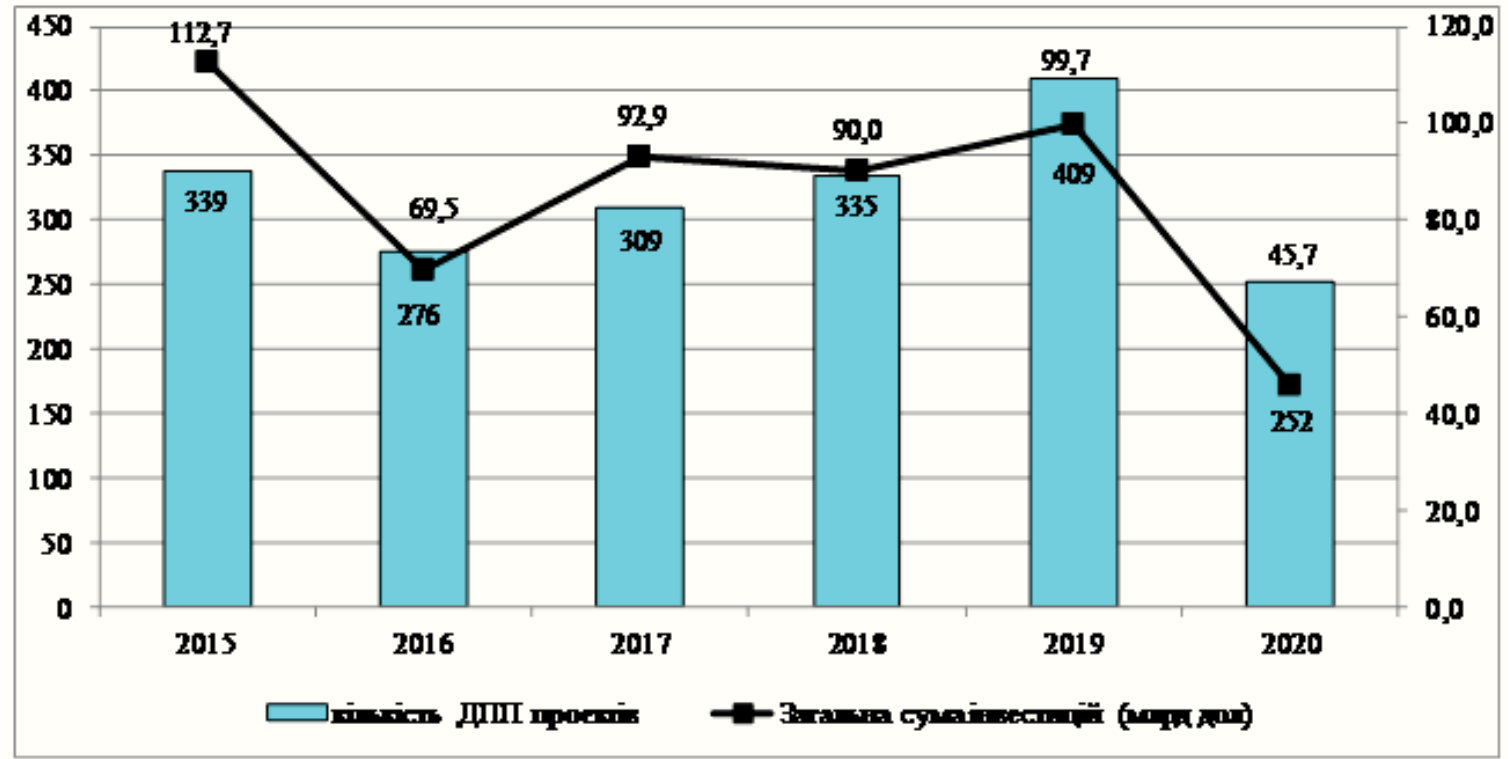

Puc. 2. Кількість проєктів ДПП та сума інвестицій, 2015-2020 рр. [22]

Як ефективний варіант організації та стимулюванні інноваційної діяльності в аграрному секторі можливо розглядати активне залучення державних ресурсів на основі державно-приватного партнерства, що дозволить стимулювати співучасть приватного сектору в інноваційних процесах, об'єднуючи можливості, розподіляючи прибутки та ризики, сприяючи розвитку конкурентного середовища та ефективному використанню бюджетних коштів [8]. Суб'єкти господарювання, які диверсифікують власну діяльність, нарощують обсяги виробництва, можуть отримати ефект від поєднання власних інтересів 3 інтересами держави в аграрному секторі, що дозволить гарантувати соціальний захист, покращити умови на місцевих ринках праці, ефективно розподіляти прибутки, забезпечити основними та оборотними засобами, отримати технологічну підтримку [4].

ДПП в аграрному секторі є формалізованим партнерством між державою та суб'єктами підприємницької діяльності, спрямоване 
на досягнення сталого розвитку сільського господарства, що передбачає вигоди держави від реалізації проекту, розподіл між учасниками інвестицій і ризиків на всіх етапах реалізації проєкту [6]. ДПП в аграрному секторі розглядають як інституційний і організаційний альянс державної влади та приватного бізнесу з метою реалізації національних і локальних пріоритетних проєктів, що здійснюється на принципах взаємовигідності та консолідації спільних зусиль [24].

Як основні напрями співпраці суб’єктів системи аграрного сектору та приватних партнерів науковці розглядають:

- обмін знаннями (прямі трансфери технологій) 3 підходами до експериментального навчання 3 акцентуванням на практичних навичках, особистій взаємодії, співпраці та програм наукового обміну;

- побудова платформ на основі приватних ресурсів для залучення відповідних партнерів, визначення стимулів, узгодження взаємних цілей та розподілу ролей та обов'язків;

- розроблення комплексних стратегій управління та зменшення ризиків;

- визначення напрямів впливу, де можливо покращити добробут і життєдіяльність агровиробників за рахунок ДПП [25].

Розвиваючи вказані напрями впровадження проєктів ДПП, можливе підвищення рентабельності діяльності в аграрному секторі, розвиток середовища для малого та середнього бізнесу виробничої сфери сільського господарства, що створює продукцію для внутрішнього та зовнішнього споживання.

Для того, щоб розкрити наявний потенціал аграрного сектору, необхідний високий рівень інвестицій у ланцюгу створення сільськогосподарської вартості. Такі інвестиції включають дослідження та технології, що підвищують продуктивність, розвиток людських ресурсів та інфраструктуру для транспорту, зберігання, переробки та збуту сільськогосподарської продукції. ДПП в аграрному секторі може забезпечити: функцію розподілу ризиків ДПП, яка може допомогти структурувати проєкти для вирішення цілого ряду галузевих ризиків (виробничий, ринковий та ін.); переваги, пов’язані з підвищенням ефективності та доступу до ринку шляхом використання інноваційних технологій і високих управлінських та маркетингових 
навичок приватного сектору; результати продовольчої безпеки та стимулювання розвитку ланцюгів створення вартості, які включають дрібних фермерів і малі та середні сільськогосподарські підприємства як ключових постачальників сировини для підприємств агробізнесу [26].

Наукова література розглядає наступні загальні різновиди проєктів ДПП в аграрному секторі: партнерства, спрямовані на розвиток виробничо-збутових ланцюжків доданої вартості в сільському господарстві для забезпечення доступу на внутрішні і зовнішні ринки (VCD); партнерства для спільних досліджень в сільському господарства, інновацій і передачі технологій, яке створюється для комерціалізації інноваційних технологій, націлених на підвищення продуктивності та доступу до ринку (ITT); партнерські відносини для побудови та модернізації ринкової інфраструктури, націлене на розвиток торгових центрів, складських приміщень, логістичних систем (MI); партнерства для надання послуг з розвитку бізнесу фермерам і малим сільськогосподарським підприємствам, включаючи розвиток ринкових інформаційних систем, субсидування послуг розвитку бізнесу (BDS) [26; 27]. Поширеними проєктами державно-приватного партнерства в агропромисловому комплексі є: впровадження інновацій (дослідження в аграрній галузі, впровадження інноваційних продуктів, які підвищують ефективність та продуктивність аграрного виробництва та доступ на ринок технологічних інновацій); оновлення об'єктів виробничої та соціальної інфраструктури в аграрній сфері (переробка та зберігання продукції, об'єкти соціальної сфери села, меліоративні системи) та ін. [3].

Основними формами державно-приватного партнерства розглядають розроблення та реалізацію цільових програм і національних пріоритетних проєктів, концесійні угоди, створення особливих економічних зон, технопарків і технополісів, формування інтегрованих структур, кластерів та інвестиційних фондів [25]. До групи договорів, що опосередковують оформлення співпраці держави та аграрного бізнесу, відносять договірні форми агроінвестиційної діяльності, наприклад: формування статутних капіталів суб'єктів аграрного підприємництва (засновницький договір, договори про 
спільну діяльність тощо); здійснення агроінвестиційної діяльності на основі агроінвестиційного договору [5]. Вбачаються перспективи у використанні механізму державно-приватного партнерства для надання агровиробникам допомоги в організації раціонального використання та охорони сільськогосподарських земель при обстеженні грунтів, складанні агрохімічних паспортів, проектів сівозмін, створенні полезахисних лісосмуг тощо [28].

Напрями реалізації проєктів ДПП мають включати як створення та модернізацію об’єктів інфраструктури так і напрями, пов'язані 3 нарощуванням потенціалу та технологіями просування продукції на ринку [29] (табл. 1).

Прикладом взаємодії держави та приватного власника у аграрній сфері в Україні є технологічний парк «Агротехнопарк» (м. Київ), де реалізуються проєкти у сфері генеруючих комплексів, які використовують біопаливо; створення та модернізації агропромислових і переробних виробництв на основі новітніх технологій; розроблення систем підвищення родючості грунтів; технології селекційної діяльності в рослинництві та тваринництві й ін. [30]. У м. Рівно створено регіональний агропромисловий інноваційний кластер «Агроінновації», заснований представниками органів державної влади, наукових та освітніх установ, виробничих підприємств та інноваційних структур. Зазначений кластер має за мету об'єднати можливості щодо розроблення та впровадження інноваційних проєктів у аграрному секторі регіону [31].

Таблиия 1.

\section{Окремі галузі діяльності ДПП у аграрному секторі}

\begin{tabular}{|c|c|c|}
\hline Галузь & $\begin{array}{c}\text { Приклади напрямів } \\
\text { / послуг }\end{array}$ & $\begin{array}{c}\text { Партнери } 3 \text { державного / } \\
\text { приватного сектору }\end{array}$ \\
\hline $\begin{array}{l}\text { Безпека харчових } \\
\text { продуктів / якість }\end{array}$ & $\begin{array}{l}\text { Норми виробництва } \\
\text { Обробка після збору вро- } \\
\text { жаю } \\
\text { Інфраструктура перероб- } \\
\text { ки } \\
\text { Інформація про ринок } \\
\text { Системи сертифікації } \\
\text { Служби відстеження } \\
\text { Маркетингові об’єднання }\end{array}$ & $\begin{array}{l}\text { Державні органи } \\
\text { Асоціації виробників } \\
\text { МСП } \\
\text { Імпортери/експортери/ } \\
\text { трейдери } \\
\text { Сертифіковані аудитори } \\
\text { Приватні лабораторії } \\
\text { Переробні підприємства }\end{array}$ \\
\hline
\end{tabular}


«Public Administration and Regional Development» https://pard.mk.ua/index.php/journal

\begin{tabular}{|l|l|l|}
\hline $\begin{array}{l}\text { Iнфраструктура: } \\
\text { загальна та галу- } \\
\text { зева }\end{array}$ & $\begin{array}{l}\text { Автошляхи } \\
\text { Інформаційно-комуніка- } \\
\text { тивні технології } \\
\text { Об’єкти логістики } \\
\text { Транспорт }\end{array}$ & $\begin{array}{l}\text { Дери } \\
\text { Дослідницькі центри } \\
\text { Розплідники } \\
\text { Фермери } \\
\text { Логістичні підприємства }\end{array}$ \\
\hline $\begin{array}{l}\text { Нарощування цен- } \\
\text { тенціалу }\end{array}$ & $\begin{array}{l}\text { Державні установи } \\
\text { Демонстраційні ферми } \\
\text { Навчання підприємництву } \\
\text { Освітні та наукові заклади } \\
\text { Ключові виробники та } \\
\text { об’єднання виробників }\end{array}$ \\
\hline
\end{tabular}

Джерело: [29].

Впровадження механізму державно-приватного партнерства в аграрному секторі має стати об'єктом стратегічного управління в межах загальноекономічної політики держави, що сприятиме стабільності інституціонального регулювання. Вбачається за необхідне при розробленні Стратегії розвитку аграрного сектору визначити державно-приватне партнерство як один із механізмів реалізації пріоритетних довгострокових напрямів та завдань, результатом виконання яких має бути усунення наявних диспропорцій та орієнтація на динамічний і стійкий розвиток [24]. Розвиток аграрної сфери шляхом ДПП передбачає застосування ризик-орієнтованого підходу в процесі реалізації контролю держави та пріоритетного фінансування інноваційних проектів в аграрній сфері. Спираючись на ланцюг «вирощування - переробка - продаж», що забезпечує проєкт ДПП кластерного об'єднання, необхідним є упровадження підприємств які мають забезпечити всі етапи аж до реалізації сільськогосподарської продукції. Наприклад, органічне виробництво, процес якого спільно контролюється приватним та державним партнерами, у вигляді кінцевої сертифікованої продукції може реалізовуватися на внутрішньому ринку (у межах кластера) та на зовнішніх ринках [32].

Процеси стратегічного планування та створення необхідної інфраструктури в аграрному секторі передбачають формування в секторальних стратегіях можливості використання співробітництва державного та приватного сектору (рис. 3). 


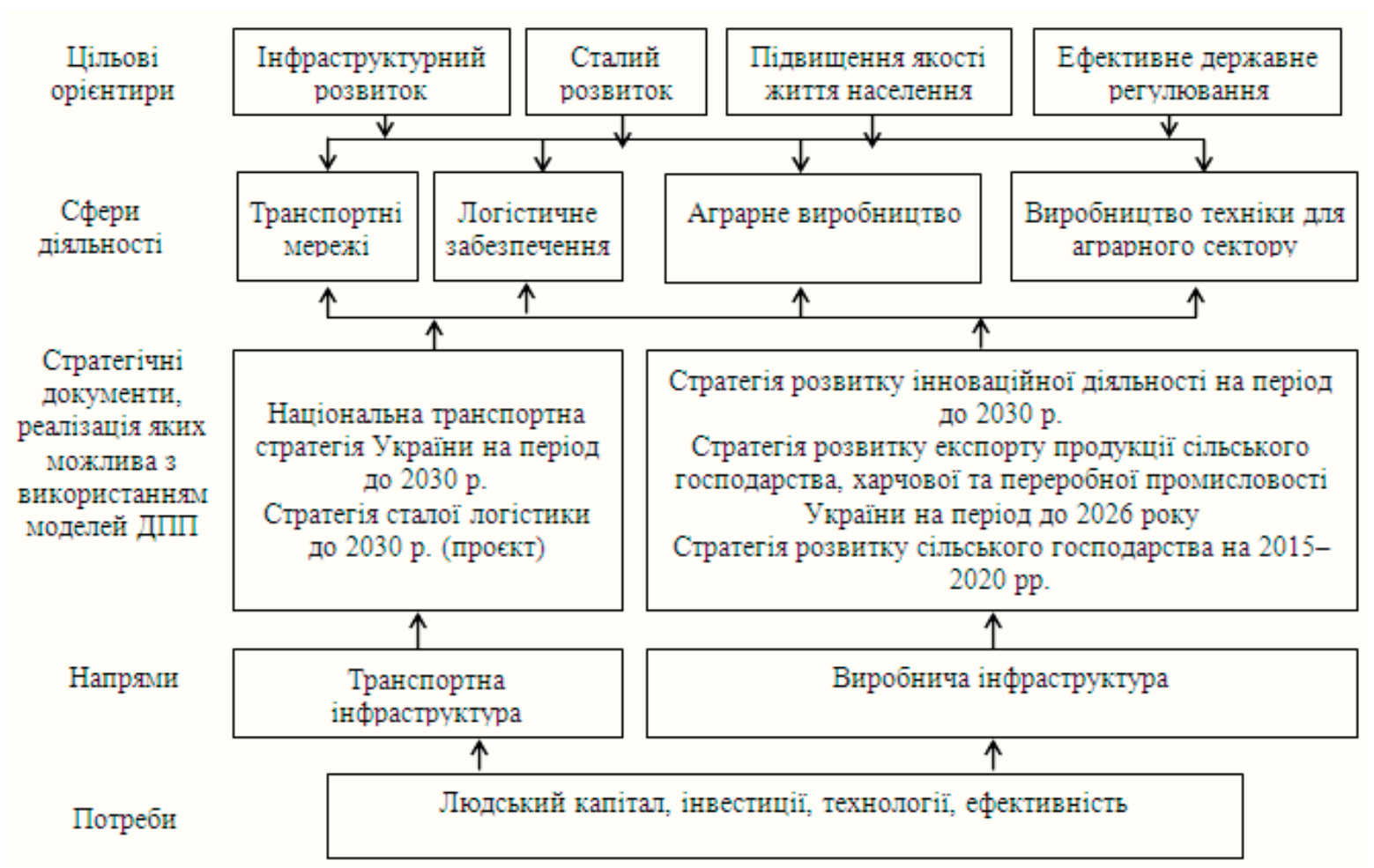

Puc. 3. Модель реалізації стратегічного планування розвитку сфер діяльності, пов'язаних з аграрним сектором, на основі можливого використання ДПП

Нажаль, продуктивному залученню моделей державно-приватного партнерства заважає відсутність затверджених окремих стратегій. Наприклад, Стратегія сталої логістики до 2030 р., яка має підвищити мобільність транспортування вантажів, залучити інвестиції у галузь вантажоперевезень, повною мірою задіяти транзитний потенціал України, а, отже зменшити втрати сільгоспвиробників через неефективну логістику, знаходиться на стадії розгляду. На часі формування та затвердження нової Стратегії розвитку сільського господарства, що прийде на заміну діючій Стратегія розвитку сільського господарства на 2015-2020 рр., де ключовим інструментом розвитку аграрного сектора буде визначено ДПП. Кардинальні зміни, що відбулися у зв'язку з процесами децентралізації та передачею земельних ресурсів сільськогосподарського призначення з державної до комунальної власності територіальних громад [33], відкриттям 3 липня 2021 р. ринку землі сільськогосподарського призначення [34] 
та інші зміни повинні віднайти відображення у майбутній Стратегії розвитку сільського господарства. Слід зазначити, що Стратегія розвитку інноваційної діяльності на період до 2030 р. визначає, що одним 3 рушіїв економічного зростання $\epsilon$ аграрний сектор, тому важливим стає розвиток його інноваційного потенціалу, в тому числі - використання державно-приватного партнерства [35].

В якості інструментів реалізації державної політики, спрямованої на розвиток аграрного сектору на основі реалізації проєктів ДПП, слід запропонувати: створення технологічних парків та бізнесінкубаторів; реалізація сільськогосподарських кластерних проєктів та ланцюгів доданої вартості; залучення венчурного капіталу та коштів інвестиційних фондів; податкове стимулювання інноваційної діяльності в аграрному секторі; компенсації відсоткових ставок за залученими кредитами на будівництво інфраструктури [32].

Доцільним $є$ аналіз існуючих у різних країнах стратегій розвитку державно-приватного партнерства в аграрній сфері. Наприклад, у Мексиці нове бачення розвитку аграрної сфери передбачає спільну ініціативу державного та приватного секторів щодо активізації та забезпечення нових напрямків для сільського господарства. Зазначені підходи розроблені у рамках Світового економічного форуму. Інституційні механізми були встановлені у окремих галузевих напрямах (олійні культури, зернові, фрукти та овочі, кава та какао) на основі партнерства держави та приватного сектору для кожної групи продуктів харчування. Кожний напрям товарної групи очолюють потужні національні або багатонаціональні корпорації з акцентом на спільні програми серед різноманітних груп компаній. Завдяки роботі у галузі очікується виграш на виробництві, збуті та збільшення інвестицій. Японія розробила стратегію «Made With Japan», що сприяє розвитку світового ланцюжка вартості продуктів харчування, особливо в країнах, що розвиваються, за допомогою ДПП. Встановлені харчові ланцюжки доданої вартості відображають кращий споживчий попит. У сфері сільськогосподарського співробітництва уряд Японії співпрацює з країнами-партнерами з метою створення ланцюжків доданої вартості, які залучають суб'єктів приватного сектору з обох сторін. Бразильське агентство сільськогосподарсь- 
ких досліджень (Embrapa) розробило стратегію для нового наукового бачення, спрямованого на дослідження на наступні 20 років. Ці зусилля координуються за допомогою програми «Agropensa», створеної в 2012 році, яка діє через мережевий підхід. «Agropensa» спеціалізується на взаємодії з відповідними зацікавленими сторонами в Бразилії та за кордоном, метою якої є виробництво та розповсюдження стратегічних знань щодо майбутніх технологічних проблем та можливостей для сільського господарства на основі партнерства між державними та приватними суб'єктами на національному та міжнародному рівнях [36].

Використання інструментарію державно-приватного партнерства в аграрному секторі має значні переваги: реалізація суспільно важливих інфраструктурних проєктів в аграрному секторі економіки за рахунок залучення ресурсів приватного сектору; підвищення конкурентоспроможності галузі [7]; модернізація основних виробничих фондів, матеріально-технічної та сировинної бази підприємств аграрного сектору; підвищення продуктивності сільського господарства; зростання якості продукції сільського господарства; відновлення стану навколишнього природного середовища [24]; додаткові можливості державного регулювання та реалізація комплексних програм в аграрній сфері; підвищення технологічного, фінансового та експортного потенціалу в сільському господарстві, в т. ч. на регіональному рівні.

Результатами реалізації проєктів ДПП в аграрному секторі слід визначити: соціальну спрямованість функціонування інфраструктури шляхом оптимізації людського потенціалу в аграрній сфері (забезпечення робочими місцями у сільській місцевості; підготовка, залучення фахівців; зменшення тенденцій до міграції); удосконалення управлінських та виробничих процесів за рахунок створення інтегрованих підприємницьких структур (кластерів), холдингів та особливих економічних зон; розширення можливостей наукової та освітньої сфер, які спеціалізуються на аграрному секторі; розвиток підприємницького середовища та соціальної відповідальності.

Можливі напрями реалізації проєктів ДПП в аграрному секторі можуть бути реалізовані при наявності відповідного інституційного 
середовища, що забезпечує основні правила та норми, які дозволяють досягти необхідних результатів. Важливими показниками є стабільність у реалізації державної політики розвитку державно-приватного партнерства та аграрної сфери, формування та впровадження стратегічних планів у зазначених сферах діяльності; ефективність та динамічність системи державного управління та регулювання, можливість управління ризиками (коливання відсоткових ставок, різкі зміни політичного курсу, зміни в податковій системі, форс-мажорні обставини); упровадження дієвої антикорупційної системи; забезпечення верховенства права; захист майнових прав та інтелектуальної власності; підтримка підприємницької діяльності; розвиток фінансових інститутів та поліпшення інвестиційного клімату.

Висновки. Отже, необхідність успішного розвитку аграрного сектору економіки України визначається використанням інноваційного інструментарію господарської діяльності та необхідних управлінських компетенцій, залучення суттєвих інвестиційних ресурсів, розподіл ризиків, посилюють необхідність використання співпраці державного та приватного секторів на основі моделей державно-приватного партнерства. У аграрному секторі моделі державно-приватного партнерства можливо визначити як довгострокові комплексні взаємовигідні договірні відносини суб'єктів державного та приватного секторів, на основі децентралізації владних повноважень, що передбачає передачу державою відповідних функцій, прав та відповідальності приватному партнеру для реалізації державних, приватних та суспільних інтересів, спрямованих на досягнення сталого розвитку сільського господарства, у процесі будівництва й експлуатації інфраструктурних об'єктів.

Визначено напрями реалізації проєктів ДПП в аграрному секторі, які передбачають розширення ринкової інфраструктури; формування агропродовольчих ланцюгів на основі кластерного підходу та створення технопарків; проєкти в сфері освіти та науки, спільних досліджень, інновацій і передачі технологій аграрного спрямування; підвищення рівня використання відновлювальної енергетики; надання послуг з розвитку бізнесу фермерам і малим сільськогосподарським підприємствам та ін. 
Визначено результати реалізації проєктів ДПП в аграрному секторі: соціальна спрямованість функціонування інфраструктури шляхом оптимізації людського потенціалу в аграрній сфері; удосконалення управлінських та виробничих процесів за рахунок створення інтегрованих підприємницьких структур, холдингів та особливих економічних зон; розширення можливостей наукової та освітньої сфер, які спеціалізуються на аграрному секторі; розвиток підприємницького середовища та соціальної відповідальності. Запропонована модель реалізації стратегічного планування розвитку сфер діяльності, пов'язаних з аграрним сектором, на основі можливого використання ДПП, передбачає формування нових стратегічних документів, пов'язаних із розвитком аграрного сектору, та прийняття оновленої Стратегії розвитку сільського господарства на середньостроковий період, де ключовим інструментом розвитку аграрного сектора буде визначено ДПП.

В основі запропонованих підходів щодо використання державно-приватного партнерства в аграрному секторі знаходиться питання забезпечення необхідного інституційного середовища, що передбачає формування та впровадження стратегічних планів у зазначених сферах діяльності; ефективність та динамічність системи державного управління та регулювання, можливість управління ризиками; впровадження антикорупційної системи; забезпечення верховенства права; захист майнових прав та інтелектуальної власності; підтримка підприємницької діяльності; розвиток фінансових інститутів; реалізація експортного потенціалу країни. Виходячи 3 зазначеного, у майбутніх дослідженнях буде розглянуто підходи до удосконалення комплексного механізму формування інституційного середовища, для розвитку аграрного сектору на основі використання ДПП.

\section{Стаття надійшла до редакції: 09.07.21}




\section{IMPLEMENTATION OF PUBLIC-PRIVATE PARTNERSHIP PROJECTS IN THE AGRICULTURAL SECTOR}

Vitalii Kruhlov, Doctor of Sciences in Public Administration, Assistant Professor Kharkiv National University of Civil Engineering and Architecture, Kharkiv, Ukraine.

Dina Tereshchenko, Doctor of Sciences in Public Administration, Assistant Professor Kharkiv National University of Civil Engineering and Architecture, Kharkiv, Ukraine.

The study analyzes the current state of development of publicprivate partnerships, the place of the agricultural sector of the Ukrainian economy in the formation of the gross domestic product and studies the key areas of cooperation between the state and the private owner based on the projects implementation in the agricultural sector. The purpose of the article is the project implementation reviewing of public-private partnership in the agricultural sector of the economy and developing of approaches to activating of the strategic directions for the development of partnerships between the public and private owners in the agricultural sector. The priorities aimed at finding additional resources that can be attracted in the process of implementing public-private partnership projects, should be at the heart of modern approaches to the development of the agricultural sector. The study indicates the guidelines for the public-private partnerships development in the agricultural sector, that proposes the exchange of knowledge, the development of overarching strategies, concessionaire agreements, the creation of special economic zones, technology parks and technopolises, the formation of integrated structures, clusters and investment funds, the development of value chains. The main forms of public-private partnership projects implementation are highlighted on the basis of existing practical experience. The directions for the implementation of public-private partnership projects in certain industries of the agricultural sector based on the creation and modernization of infrastructure facilities and technologies for promoting 
products on the market are proposed. A model has been developed for the implementation of strategic planning for the development of activity areas related to the agricultural sector, based on the possible usage of public-private partnership projects. As the main tools in the development of public-private partnership projects in the agricultural sector, it is proposed formation of a Strategy for the development of agriculture, implementation of agricultural cluster projects and value chains, tax incentives for innovation activities in the agricultural sector, improvement of the investment environment, creation of technology parks and business incubators, improvement of the legal framework, innovative development, etc.

Key words: public-private partnership, agricultural sector, state, projects, innovative development, strategies.

\section{Received: 09.07.21}

\section{References}

1. Ukrainian Institute of the Future (2020). Ukrai'na - svitovyj supermarket ekologichnyh produktiv [Ukraine - the World's Supermarket of Eco-Friendly Products]. Retrieved from https://strategy.uifuture.org/ ukraina\%E2\%80\%93sv\%D1\%96toviy-supermarket-ekolog\%D1\%96chnixprodukt\%D1\%96v.html [in Ukrainian].

2. Radchenko, O. P. (2019). Problemy ta tendentsii vykorystannia derzhavno-pryvatnoho partnerstva $\mathrm{v}$ APK $\mathrm{v}$ umovakh hlobalizatsii. [Problems and trends of use of public-private partnership in agricultural complex in the globalization conditions]. Pryazovskyi ekonomichnyi visnyk, 6(17), 53-56. [in Ukrainian].

3. Kosach, I. A., \& Starchenko, G. V. (2018). Intehratsiini protsesy ta derzhavno-pryvatne partnerstvo v APK Ukrainy: mozhlyvosti ta perspektyvy [The integration processes and state-private partnership in aic of Ukraine: opportunities and perspectives]. Visnyk Cherkaskoho universytetu. Seriia : Ekonomichni nauky, 1, 62-69 [in Ukrainian].

4. Kozin, M., Pyrchenkova G., \& Radchenko E. (2020). Public-private partnership in the agricultural sector: empirical estimation by factorial characteristics. E3S Web of Conferences, 175, 13016 [in English]. 
5 Hryhorieva, Kh. A. (2019). Derzhavna pidtrymka silskoho hospodarstva Ukrainy : problemy pravovoho zabezpechennia [State support of agriculture of Ukraine : problems of legal support], Helvetyka, Kherson [in Ukrainian].

6. Latynin, M. A., \& Zaskalkina, O. M. (2017). Perspektyvy rozvytku mehanizmiv derzhavnogo reguljuvannja instytucional'nogo seredovyshha V agrarnomu sektori ekonomiky Ukrai'ny [Perspectives of development of mechanisms of regulation of the institutional environment in the agricultural sector of Ukraine]. International scietific journal «Internauka», 10, 14-22 [in Ukrainian].

7. Ratushna, T. (2016). Biznes-inkubator mizhrehionalnoho typu: forma stymuliuvannia innovatsiinoi diialnosti $\mathrm{v}$ silskomu hospodarstvi [Business incubator of interregional type: a form of stimulation of innovation activities in agriculture]. Zbirnyk naukovykh prats Cherkaskoho derzhavnoho tekhnolohichnoho universytetu. Seriia : Ekonomichni nauky, 41(1), 75-83 [in Ukrainian].

8. Rudenko O. M. (Ed.). (2016). Publichne upravlinnja ta administruvannja : slovnyk [Public management and administration: a dictionary]. Kyiv [in Ukrainian].

9. FAO. (2020). The State of Agricultural Commodity Markets 2020. Agricultural markets and sustainable development: Global value chains, smallholder farmers and digital innovations. Rome, FAO. doi: https://doi.org/10.4060/ cb0665en [in English].

10. OECD-FAO. (2015). Agricultural outlook 2015. Paris: FAO, OECD Publishing. Retrieved from www.fao.org/3/a-i4738e.pdf [in English].

11. OECD. (2020). Agricultural Policy Monitoring and Evaluation 2020. Paris: OECD Publishing. doi: https://doi.org/10.1787/928181a8-en [in English].

12. OECD-FAO. (2020). Agricultural Outlook 2020-2029. Paris: FAO, OECD Publishing. doi: https://doi.org/10.1787/1112c23b-en [in English].

13. NBU. (2020). Infljacijnyj zvit. Zhovten' 2020 roku. [Inflation Report, October 2020]. Retrieved from https://bank.gov.ua/monetary/report [in Ukrainian].

14. Yost, M. A., Sudduth, K. A., Walthall, C. L., Kitchen N. R. (2019). Public-private collaboration toward research, education and innovation opportunities in precision agriculture. Precision Agriculture, 20(1), 4-18 [in English].

15. Casady, C. B., Eriksson, K., Levitt, R. E. \& Scott, W. R. (2019). (Re) defining public-private partnerships (PPPs) in the new public governance (NPG) paradigm: an institutional maturity perspective. Public Management Review, 22(2), 161-183 [in English]. 
16. The World Bank. (2019). What are public private partnerships?. Retrieved from https://ppp.worldbank.org/public-private-partnership/overview/ what-are-publicprivate-partnerships [in English].

17. Mota, J. A. \& Moreira, A. C. (2015). The importance of non-financial determinants on public-private partnerships in Europe. International Journal of ProjectManagement, 33(7), 1563-1575 [in English].

18. Malik, S., \& Kaur, S. (2020). Multi-dimensional public-private partnership readiness index: a sub-national analysis of India. Transforming Government: People, Process and Policy [in English].

19. Rocca, M. E. (2017). The Rising Advantage of Public-Private Partnerships, McKinsey and Company. Retrieved from www.mckinsey.com/industries/capitalprojects-and-infrastructure/our-insights/the-rising-advantageof-public-privatepartnerships [in English].

20. Lop, N. S., Ismail, K. \& Isa, H. M. (2016). Performance assessment framework for private finance initiative projects in Malaysia, in MATEC Web of Conferences 66, IBCC. EDP Sciences. doi: 10.1051/matecconf/20166600049 [in English].

21. Sharma, P., \& Gupta, S. (2017). The Exceptive Scrutiny of PublicPrivate Partnership Models for Colossal Infrastructure Projects. International Conference on Innovative Concepts in Commerce, Management and Computer Science. Poona College of Art, Science and Commerce, 1-14 [in English].

22. The World Bank. (2020). PPI Project Database. Retrieved from http:// ppi.worldbank.org [in English].

23. The World Bank. (2020). Private Participation in Infrastructure (PPI) 2020. Retrieved from https://ppi.worldbank.org/en/ppi [in English].

24. Kosach, I., \& Zhurman, S. (2019). Derzhavno-pryvatne partnerstvo v APK Ukrai'ny: strategichni aspekty [Public-private partnership in AIC of Ukraine: strategic aspects]. Problemy i perspektyvy ekonomiky ta upravlinnja, 4(20), 127-136 [in Ukrainian].

25. Shubravska, O. V (2020). Korporatyzatsiia ahrarnoho sektora ekonomiky Ukrainy [Corporatization of the agricultural sector of the Ukrainian economy]: kolektyvna monohrafiia. Kyiv: NAN Ukrainy, DU «In-t ekon. ta prohnozuv. NAN Ukrainy». Retrieved from http://ief.org.ua/docs/mg/329.pdf [in Ukrainian].

26. Rankin, M. et al. (2017). Public-Private Partnerships for Agricultural Transformation - Trends and Lessons from Developing Countries. In The Em- 
erald Handbook of Public-Private Partnerships in Developing and Emerging Economies (pp. 191-219). Emerald Publishing Limited [in English].

27. Reznik, N. et al. (2019). Development of Public-Private Partnerships in The Agrarian Sector of Ukraine: Digitalization as a Priority. International Journal of Recent Technology and Engineering (IJRTE), 8(3), 275-281 [in English].

28. Semchyk, V. I., \& Kulynych, P. F. (2015). Pravovi problemy publichnopryvatnoho partnerstva $\mathrm{v}$ ahrarnykh i zemelnykh vidnosynakh [Legal problems of public-private partnership in agrarian and land relations]. Kyiv: Naukova dumka [in Ukrainian].

29. Menezes, A., Ridler, N., \& Murekezi, P. (2018). Contract farming and public-private partnerships in aquaculture. Lessons learned from East African countries. - Food and Agriculture Organization of the United Nations [in English].

30. Besprozvannykh, O. O. (2020). Rozvytok infrastrukturnogo zabezpechennja innovacijnoi' dijal'nosti promyslovogo pidpryjemstva [Development of infrastructure support of industrial enterprise's innovative activity]. (Candidate's thesis). Kharkiv: National technical university «Kharkiv polytechnic institute» [in Ukrainian].

31. Onipko, T. A. (2019). Innovacijno-klasternyj rozvytok jak chynnyk zrostannja konkurentospromozhnosti ekonomichnyh system [Innovation-cluster development as a factor of growth of competitiveness of economic systems]. Candidate's thesis. Poltava: Higher Educational Establishment of Ukoopspilka «Poltava University of Economics and Trade» [in Ukrainian].

32. Kruhlov, V. V. (2020). Mekhanizmy derzhavnoho rehuliuvannia rozvytku derzhavno-pryvatnoho partnerstva $\mathrm{v}$ Ukraini [Mechanisms of state regulation of public-private partnership development in Ukraine]. (Doctor's thesis). Kharkiv: Kharkiv regional institute of public administration of National academy of public administration by the President of Ukraine [in Ukrainian].

33. On some measures to accelerate reforms in the field of land relations: Decree of the President of Ukraine on October 15, 2020, № 449/2020 Retrieved from https://zakon.rada.gov.ua/laws/show/449/2020\#Text. [in Ukrainian].

34. About modification of some legislative acts of Ukraine concerning conditions of circulation of lands of agricultural purpose: Law of Ukraine on March 31, 2020 № 552-IX Retrieved from https://zakon.rada.gov.ua/laws/ show/552-20\#Text. [in Ukrainian].

35. On approval of the Strategy for the Development of the Sphere of Innovation for the Period up to 2030: Order of the Cabinet of Ministers of 
Ukraine; Strategy on July 10, 2019 № 526-p Retrieved from https://zakon.rada. gov.ua/laws/show/526-2019-\%D1\%80\#Text. [in Ukrainian].

36. Moreddu, C. (2016). Public-Private Partnerships for Agricultural Innovation: Lessons From Recent Experiences. OECD Food, Agriculture and Fisheries Papers, №. 92, OECD Publishing, Paris. doi: http://dx.doi. org/10.1787/5jm55j9p9rmx-en [in English].

37. Kvitka S., Borodin E., Koval V., Yemelyanov V., Ivashova L. (2019). Innovative mechanisms of the cross-sectoral interaction between business and public authorities in conditions of information society's transformation. Revista Dilemas contemporáneos: Educación, Politica y Valores. Year VII, Special Edition, November 2019. Leer más: https://dilemascontemporaneoseducacionpoliticayvalores.com/_files/200006309-752b8752ba/EE\%2019.11.133\%20Mecanismos $\% 20$ innovadores $\% 20 \mathrm{de} \% 201 \mathrm{a} \% 20$ interacci $\% \mathrm{C} 3 \% \mathrm{~B} 3 \mathrm{n} \% 20$ intersectorial....pdf [in English].

\section{Відомості про авторів / Information about the Authors}

Круглов Віталій Вікторович: Харківський національний університет будівництва та архітектури: вул. Сумська, 40, м. Харків, 61002 , Україна.

Vitalii Kruhlov: Kharkiv National University of Civil Engineering and Architecture: Sumska str. 40, Kharkiv, 61002, Ukraine.

\section{ORCID.ORG./ 0000-0002-7228-8635}

\section{E-mail: virt197@gmail.com}

Терещенко Діна Акрамівна: Харківський національний університет будівництва та архітектури, вул. Сумська, 40, м. Харків, 61002, Україна.

Dina Tereshchenko: Kharkiv National University of Civil Engineering and Architecture: Sumska str. 40, Kharkiv, 61002, Ukraine.

ORCID.ORG./ 0000-0003-0633-0097

\section{E-mail: dtereshchenko7754367@ukr.net}

